\title{
APPLICATION OF THE METABOLIC PROFILE TEST IN THE PREDICTION AND DIAGNOSIS OF FATTY LIVER IN HOLSTEIN COWS
}

\author{
ŠAMANC H*, KIROVSKI DANIJELA*, STOJIĆ V*, STOJANOVIĆ DRAGICA**, VUJANAC I*, \\ PRODANOVIĆ $R^{\star}$ and BOJKOVIĆ-KOVAČEVIĆ SLAVICA*** \\ *University of Belgrade, Faculty of Veterinary Medicine, Serbia \\ **Scientific Veterinary Institute "Novi Sad", Novi Sad, Serbia \\ ***Veterinary station, Agriculture Cooperation Belgrade, Serbia
}

(Received 15th June 2011)

The aim of this study was to examine the possibility of using results of metabolic profile test in the prediction and diagnosis of fatty liver in Holstein cows. Forty dry cows, 5 to 7 days before calving, were chosen from the commercial dairy herd and included in the study. Four blood samples were taken by jugular venipuncture from each animal: 5 to 7 days before expected calving (dry period), as well as on day 12, 30 and 60 of lactation. Concentrations of glucose, $\beta$-hydroxybutyrate (BHBA), total protein, albumin, urea, total bilirubin, calcium and phosphorus concentrations were measured in all blood samples. On day 12 after calving, liver percutaneous biopsies were obtained using a biopsy instrument. Liver tissue lipid content was determined by pathohistological determination. Cows were divided into two groups of equal size based on the degree of lipid accumulation in the liver: healthy cows $(0.00$ fat, $n=20)$ and cows with fatty liver syndrome $(>20 \%$ fat, $n=20$ ). Milking was measured each day from day 7 to day 60 of lactation. Results showed that 5 to 7 days before calving, as well as 12 days after calving, BHBA concentrations were significantly higher $(p<0.001$, respectively) in diseased cows than in healthy cows. Additionally, the concentration of glucose was significantly lower $(p<0.01)$ and the concentration of total bilirubin significantly higher $(p<0.001)$ in diseased compared to healthy cows, at day 12 of lactation. Thirty days after calving, concentrations of albumin, glucose, $B H B A$ and Ca were significantly lower in diseased compared to healthy cows $(p<0.05, p<0.01, p<0.01$ and $p<0.001$, respectively). At day 60 after calving, concentrations of biochemical parameters did not differ between diseased and healthy cows. The lactation curve differed in diseased compared to healthy cows, starting from day 26 of lactation. Starting form that day until day 60 of lactation average daily milk production was significantly higher in healthy than in diseased cows, except on day 32 of lactation when the difference was not significant. Based on these results it can be concluded that the metabolic profile test may be a reliable tool for the prediction and diagnosis of fatty liver in Holstein cows.

Key words: fatty liver, Holstein cows, metabolic profile test 


\section{INTRODUCTION}

The metabolic profile, a series of specific blood analytical tests, is routinely used to reveal metabolic problems in dairy cattle (Payne et al., 1970; Stengärde et al., 2008; Gross et al., 2011). It involves collecting blood samples from eight to twelve cows at 4 time periods relative to calving (dry, puerperium, peak lactation and midlactation) and measuring selected blood metabolites (Oetzel, 2004). The metabolic profile test involves measuring concentrations of blood glucose, $\beta$ hydroxybutyrate (BHBA), non esterified fatty acid (NEFA), trygliceride, total lipids, cholesterol, total protein, albumin, blood urea nitrogen, total bilirubin, aspartat aminotransferase (AST), gamma-glutamyl transferase (GGT), calcium (Ca), inorganic phosphorus (iP) and magnesium (Mg) (Kida, 2002). Our experience showed that relevant metabolic indicators of energy status are concentration of glucose and BHBA (Prodanović et al., 2010). Although concentration of NEFA is more sensitive to energy balance changes in transition cows, concentration of BHBA is most commonly used (Ospina et al., 2010). The reason is the high cost of reagents for NEFA determination and instability of NEFA in frozen blood serum. Protein status can be determined by analyzing results for concentrations of total protein, albumin and urea. Urea concentrations are influenced by a variety of interrelated parameters including: dietary protein intake and rumen degradability, dietary amino acid composition, protein intake relative to requirement, liver and kidney function, muscle tissue breakdown, dietary carbohydrate amount and rumen degradability (Laven et al., 2007). Total protein and albumin reflect the availability of protein and their concentration decline in the face of protein deficiency. However, this occurs over a period of time. Albumin has a relatively long half-life and can reflect protein deficiency problems over a period of a month or two (Alberghina et al., 2011).

Liver function can be assessed through a variety of enzymes (glutamate dehtydrogenase (GLDH) gamma-glutamyltransferase (GGT), aspartate aminotransferase (AST) and sorbitol dehydrogenase (SDH) and total bilirubin concentrations in the blood (Gerloff and Herdt, 1984). Unfortunately, an elevation in any of these parameters does not mean anything more than some insult to the liver has occurred. Additionaly, liver enzymes activity has high variability and so low diagnostic values. Althought bilirubin values are most specific to bile flow problems than overt liver cell damage, our experience showed that there is a strong relationship between fatty liver and total bilirubin concentration in the blood.

Macrominerals calcium $(\mathrm{Ca})$, phosphorus $(\mathrm{P})$ and magnesium $(\mathrm{Mg})$ are of extreme interest as to their status relative to their role in some metabolic problems (milk fever, alert downer cows and weak cow syndrome). Unfortunately, most of these minerals are tightly regulated in the body through a variety of homeostatic processes. Blood concentrations of macrominerals are not reflective of dietary status when the homeostatic system is functioning properly. Phosphorus and Mg are macrominerals in which blood concentrations are somewhat sensitive to dietary intake. Assessment of $\mathrm{Ca}$ concentrations around the time of calving is a useful indicator of how well the Ca regulatory system is working and potential for 
clinical or subclinical hypocalcemia problems. Other than the 2 weeks prior to and following calving, blood $\mathrm{Ca}$ is not a very sensitive diagnostic measure as a result of the intact regulatory system (Goff, 2004). Therefore macromineral blood concentrations will need to be carefully interpreted in the light of whether or not the homeostatic system is in proper operation.

For proper interpretation of the metabolic profile it is necessary to analyze all blood metabolites together, not separately one by one.

Fatty liver is a major health problem in high yielding dairy cows in early lactation (Goff and Horst, 1997; Mulligan and Doherty, 2008). Nutritional factors such as obesity are crucial in fatty liver etiology. Obese cows have a greater decrease in feed intake during the peripartal period and, therefore, have a more severe negative energy balance during early lactation (Stockdale, 2001). That leads to increased lipolysis of adipose tissue. Nonesterified fatty acids (NEFA) that are released from the stored triacylglycerol (TAG) in the adipose tissue are readily taken up by liver where they provide energy for liver function. If more NEFA arrive at the liver that needed for energy purposes, the excess may be oxidized incompletely and generate ketone bodies (Hanigan, 2004) or be converted to TAG for deposition. Under normal conditions, TAG are secreted from the liver as very-low-density lipoproteins (VLDL). Inadequate secretion of VLDL, however, contributes to development of fatty liver (Bobe et al., 2004).

The aim of this study was to monitor metabolic profil in dairy herds with different fatty liver incidence in order to investigate its purposes in the prediction of fatty liver.

\section{MATERIAL AND METHODS}

\section{Animals}

Forty dry cows were chosen from the commercial dairy herd and placed in the study. The cows ranged from 4 to 6 years of age. The cows were placed in a tie-stall barn.

\section{Blood sampling}

Four blood samples were taken by jugular venipuncture from each animal: the first 5 to 7 days before expected calving (dry period), the second 12 days after calving (puerperal period), the third 30 days after calving and fourth 60 days after calving. Samples were subsequently centrifuged at $1000 \mathrm{~g}$ for 20 minutes, and the serum was decanted and stored at $-18^{\circ} \mathrm{C}$ until analyzed. To compare blood metabolite concentrations without influence of daily rhythms, samples were taken 4 to 6 hours after the morning feeding.

Analyses

Blood glucose and $\beta$-hydroxibutyrate (BHBA) concentrations were measured by using commercial test bands (Precision-Xtra plus). The serum total protein (TP), albumin, urea, total bilirubin, calcium and phosphorus concentrations were measured by using the automatic analyzer with commercial kits (Bio-Merieux). 


\section{Liver biopsy}

On day 12 after calving, liver percutaneous biopsies were obtained using a biopsy instrument following the method of Hojovcova and Kacafirek (1967) and described in details by Samanc et al. (2010). Liver tissue lipid content was determined at the Pathomorphology Department at the Faculty of Veterinary Medicine, University of Belgrade. For pathohistological determination of lipids, sections were made using a freezing microtome and stained with Sudan III. Lipid content in the hepatocytes was determined through computer image analysis (Software Q Win). Cows were divided into two groups of equal size based on the degree of lipid accumulation in the liver: healthy cows $(<20 \%$ fat, $n=20)$ and cows with fatty liver syndrome ( $>20 \%$ fat, $n=20$ ).

\section{Milking values}

Milking was measured daily from day 7 to day 60 of lactation. Milk production was monitored at the morning and evening milking $\left(6^{00}\right.$ and $\left.18^{00}\right)$. Measurements were performed with an automatic milking machine "Delaval".

\section{Statistical Analysis}

All results are expressed as means \pm SD. Student $t$ test was done to identify differences between groups. The differences were considered significant at $p<0.05$. Correlations between fatty liver degree and the determined blood parameters are also presented using Pearson correlation coefficients.

\section{RESULTS}

According to content of lipids in the liver at day 12 after calving, cows were divided into two groups: healthy cows ( $n=20 ; 0.00 \pm 0.00 \%$ fat) and diseased cows ( $n=20 ; 28.50 \pm 6.27 \%$ fat).

Blood metabolite concentrations in healthy and diseased cows during dry period i.e. 5 to 7 days before calving, are shown in Table 1 .

It can be seen from table 1 that there was no significant difference in blood metabolite concentrations between two examined groups of cows, excepted for BHBA concentrations. BHBA concentrations were significantly higher $(p<0.001)$ in diseased cows than in healthy cows.

Blood metabolite concentrations in healthy and diseased cows during the puerperal period i.e. at day 12 of lactation are shown in Table 2.

Concentrations of parameters that indicate protein status of cows (total protein, albumin and urea) are not statistically different between groups. The concentration of glucose was significantly lower $(p<0.05)$, while concentrations of BHBA and total bilirubin were significantly higher $(p<0.001$, respectively) in diseased cows.

Blood metabolite concentrations in healthy and diseased cows at day 30 of lactation are shown in Table 3.

At day 30 after calving concentrations of total protein, albumin, glucose, BHBA and $\mathrm{Ca}$ are significantly lower in diseased compared to healthy cows $(p<0.05, p<0.01, p<0.01, p<0.001$ and $p<0.05$, respectively). 
Acta Veterinaria (Beograd), Vol. 61, No. 5-6, 543-553, 2011.

Samanc $\mathrm{H}$ et al: : Application of the metabolic profile test in

the prediction and diagnosis of fatty liver in Holstein cows

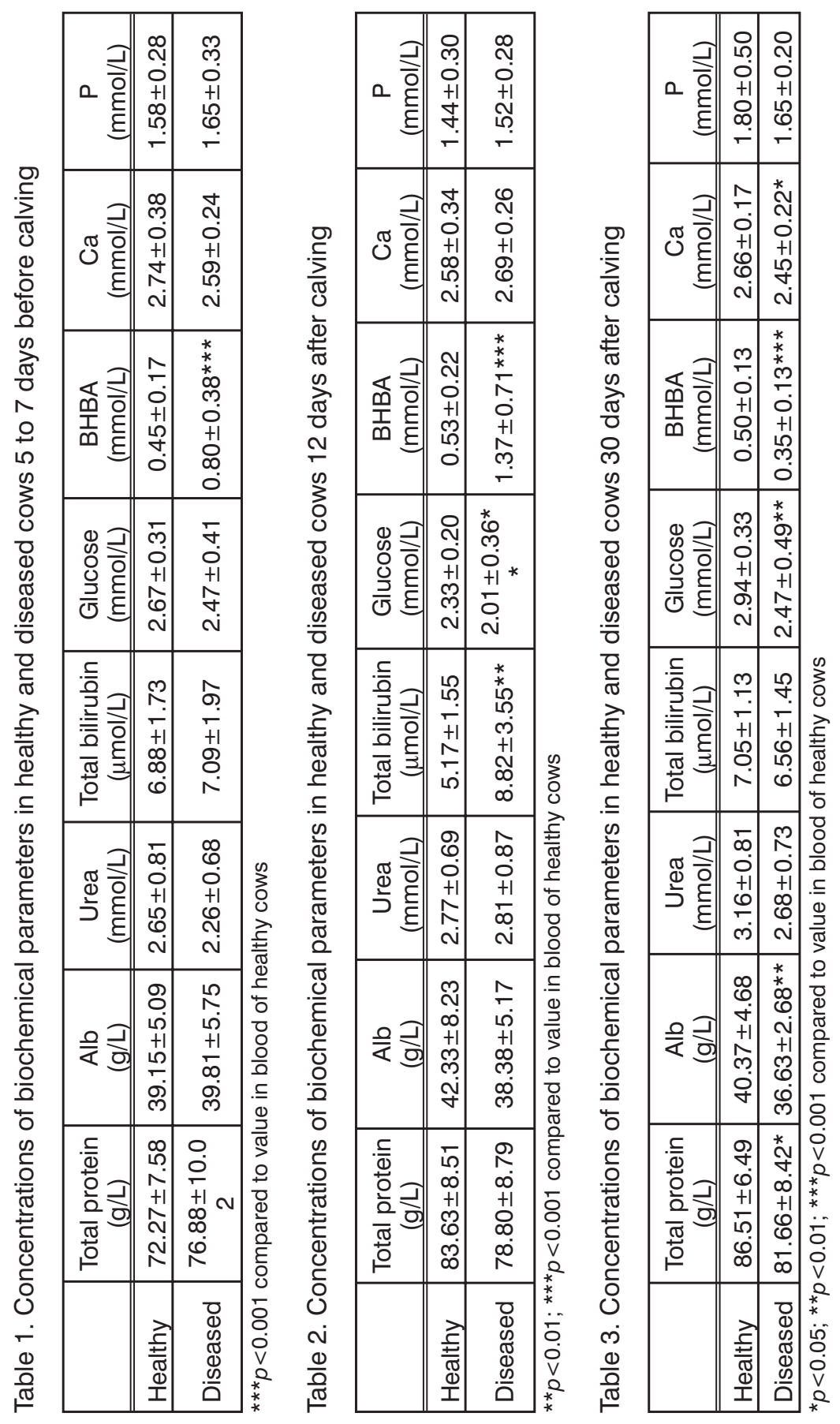




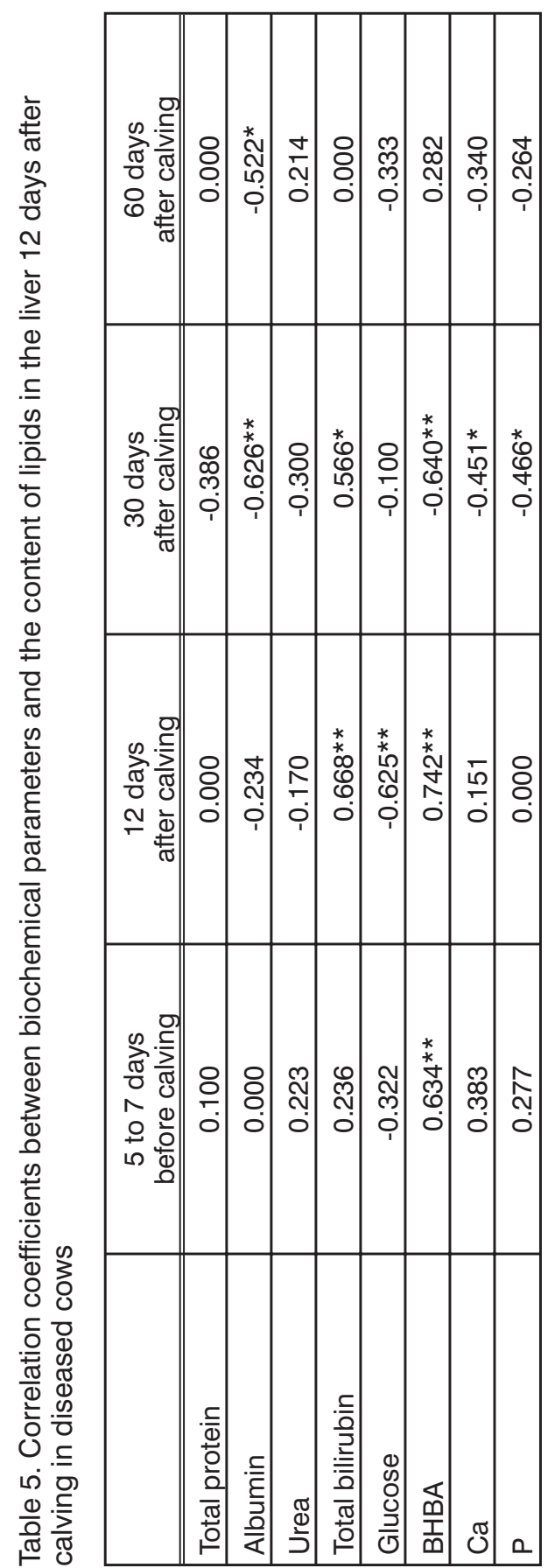


Acta Veterinaria (Beograd), Vol. 61, No. 5-6, 543-553, 2011.

Samanc $\mathrm{H}$ et al.: Application of the metabolic profile test in

the prediction and diagnosis of fatty liver in Holstein cows

Blood metabolite concentrations in healthy and diseased cows at day 60 of lactation are shown in Table 4.

Trend of changes in metabolic parameters that characterized cows at day 30 of lactation were mainly, still present at day 60 of lactation, although differences in blood parameters between groups were not significant.

Correlation coefficient's between determined parameters and the content of lipid in liver of cows are shown in Table 5.

Concentration of BHBA showed significant positive correlation with puerperal fatty liver degree at the dry period and early puerperal period. Concentration of glucose showed significant negative correlation with fatty liver degree during puerperium. At the same time the concentration of total bilirubin showed a significant positive correlation with fatter liver degree. At day 30 of lactation concentrations of albumin, BHBA, Ca and $\mathrm{P}$ showed significant negative correlation with puerperal fatty liver degree. Additionaly, there was a significant positive correlation between total bilirubin concentration and puerperal fatty liver degree. Significant negative correlation was calculated between albumin concentration at day 60 and puerperal fatty liver degree.

Average daily milk production of healthy and diseased cows from day 7 until day 60 of lactation is shown in Figure 1.

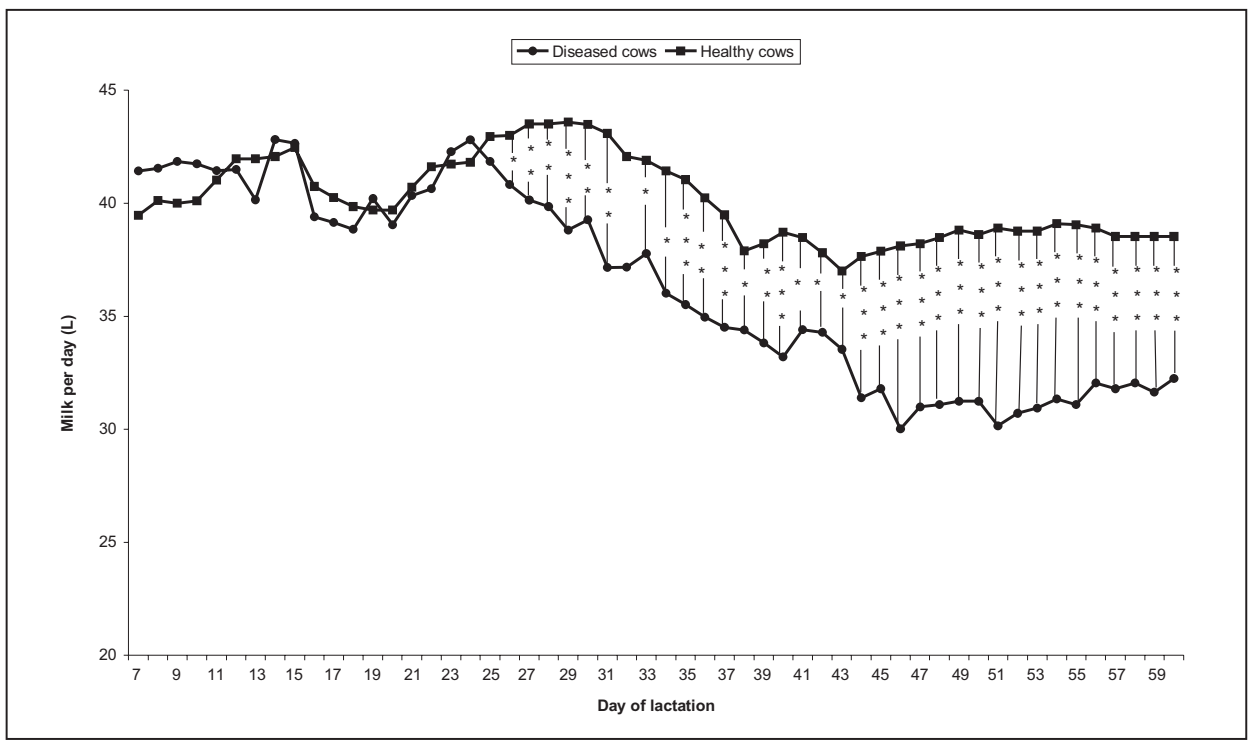

Graph 1. Milk production from day 7 to day 60 of lactation in healthy and diseased cows

Milk production did not significantly differ between healthy and diseased cows until day 25 of lactation. From day 26 of lactation daily milk production was lower in diseased compared to healthy cows and differences were statistically significant except for day 32 of lactation. At day 30 of lactation average milk production in healthy cows was $(43.49 \pm 3.89 \mathrm{~L} /$ day $)$ and was significantly higher 
$(p<0.01)$ than in diseased cows $(39.26 \pm 3.89 \mathrm{~L} /$ day $)$. At day 60 of lactation average milk production in healthy cows $(38.52 \pm 3.23 \mathrm{~L} /$ day) was significantly higher $(p<0.01)$ than in diseased cows $(33.20 \pm 4.88 \mathrm{~L} /$ day $)$.

\section{DISSCUSION}

Concentrations of biochemical parameters during the dry period may be a good indicator of metabolic changes that may finally lead to postpartal metabolic diseases (Kida, 2002). Our results showed that a week before calving, concentration of BHBA was significantly higher in diseased compared to healthy cows. This result indicates that in cows with postpartum fatty liver, ketogenesis is higher, probably due to lipomobilization that starts during the dry period. It is well known that NEFA concentration is a more direct indicator of lipomobilization, but it is not a widely used parameter under filed condition (Ospina et al., 2010). It is a still open question what initiates lipomobilization when cows are in the state of positive energy balance i.e. dry period. According to Rukkwamsuk et al. (1999) obese cows are more prone to lipomobilisation due to restricted appetite around calving. On the other hand, Šamanc et al. (2010) concluded that the endocrine status of dry cows is the most important factor that initiates lipomobilization. He emphasizes the role of low thyroid hormone concentration on lipid metabolism disorder during the dry period. Due to the fact that all cows from our study were on the same feeding regime, it is more probable that differences in the endocrine status are a triggering factor that provoke disturbances in lipid metabolism. There is a significant positive correlation between BHBA concentration in the dry period and postpartal fatty liver degree (Table 5) which indicate that changes in BHBA concentrations during the dry period can be used as a tool for the prediction of fatty liver. Concentration of glucose was slightly lower in diseased compared to healthy cows, but the difference was not significant $(p=0.09)$. Anyway, glycemia was within the physiological range in both groups of cows during the dry period.

Glucose concentration at day 12 after parturition was significantly lower compared to the dry period in both groups of cows ( $p<0.001$, respectively). This was expected due to increased milk production. Namely, blood glucose is partly used for milk lactose syntesis, partly in other metabolic pathways in the mammary gland (Lemosquet et al., 2009). Anyway, in diseased cows glucose concentration is under physiological limits which indicate that there is not enough gluconeogenic precursors or that gluconeogenesis is impaired (Hammon et al., 2009). In addition, there was a high negative correlation between postpartal glucose concentrations and fatty liver degree (Table 5). Ketogenesis is increased since fatty acid oxidation rote in liver cells is blocked by insufficient supply of glucose. There was a high positive correlation between puerperal BHBA concentration and fatty liver degree (Table 5). This finding was consistent with other observations (Gröhn et al., 1983). Total bilirubin concentration was significantly higher in cows with fatty liver and may be a reliable indicator of fatty liver in dairy cows as shown earlier by other authors, too (Kalaitzakis et al., 2006; 2010). Total bilirubin concentration is increased due to impaired morphological 
and functional integrity of the liver. Concentrations of total bilirubin were positively correlated with liver lipid content (Table 5).

Results obtained at days 30 and 60 of lactation are important to the determine duration of the liver disfunction. Findings in the metabolic profile test obtained at day 30 of lactation indicate that liver function is still impaired. Lower total protein and albumin concentrations are determined in diseased cows probably due to impaired function of the liver to synthesize albumins (Braun et al., 1986). Lower glycemia indicate on impaired gluconeogenesis (Nafikov and Baitz, 2007). Lower BHBA in diseased cows may be explained by lower ketogenesis (Mohamed et al., 2000). On the other hand, these cows have lower milk production and therefore no need for increased mobilization of endogenous fat reserves (Figure 1). Lower calcium concentration in diseased cows is probably due to impaired hepatic hydroxylation. Defective hydroxylation, could be a factor in 25-hydroxyvitamin $\mathrm{D}$ depletion which leads to depressed $\mathrm{Ca}$ absorption and consequently to hypocalcemia (Schröder and Breves, 2006). Fatty liver leads to hypophoshatemia either through decreasing its dietary intake (Forrester et al., 1989) or due to ketoacidosis, developed during pathogenesis of fatty liver (Knochel, 1977). Results for the correlation coefficient calculated between blood parameters determined at day 30 of lactation and postpartal fatty liver degree support this discussion (Table 5).

At day 60 of lactation the metabolic profile test is still different in diseased compared to healthy cows. Since these differences were not statistically significant it means that hepatic function is restored. There are not enough literature data about duration of fatty liver in dairy cows but, according to our biochemical results, it may be supposed that duration of fatty liver is shorter than 60 days.

Based on presented results it can be concluded that the metabolic profile test can be used as a reliable method for the prediction and diagnosis of fatty liver in Holstein dairy cows.

ACKNOWLEDGEMENTS:

This work was supported by Ministry of science and technology, Republic of Serbia, Project Grant No 46002 .

Address for correspondence:

Danijela Kirovski, DVM, PhD

Department of Physiology and Biochemistry

Faculty of Veterinary Medicine

University of Belgrade

11000 Belgrade, Serbia

E-mail: dani@vet.bg.ac.rs

\section{REFERENCES}

1. Alberghina D, Giannetto C, Vazzana I, Ferantelli V, Piccione G, 2011, Reference intervals for total protein concentrations, serum protein fractions, and albumin/globulin ratio sin clinically healthy dairy cows, J Vet Diag Invest, 21, 111-4.

2. Braun JP, Bézille P, Rico AG, 1986, Biochemical semiology of the liver in ruminants, Reprod Nutr Dev, 26, 227-43. 
3. Gerloff $B J$, Herdt TH, 1984, Hepatic lipidosis from dietary restriction in nonlacting cows, J Am Vet Med Assoc, 185, 223-4.

4. Goff JP, 2004, Macromineral disorders of the transition cow, Vet Clin North AM Food Anim Pract, 20, 471-94.

5. Gröhn Y, Lindberg LA, Bruss ML, Farver TB, 1983, Fatty infiltration of liver in spontaneously ketotic dairy cows, J Dairy Cows, 66, 2320-8.

6. Gross J, van Dorland HA, Bruckmaier RM, Schwarz FJ, 2001, Performance and metabolic profile of dairy cows during a lactation and deliberately induced negative energy balance with subsequent realimentation, J Dairy Sci, 94, 1820-30.

7. Hammon HM, Stürmer G, Schneider F, Tuchscherer A, Blum H, Engelhard T et al., 2009, Performance and metabolic and endocrine changes with emphasis on glucose metabolism in high-yielding dairy cows with high and low content in liver after calving, J Dairy Sci, 92, 1554-66.

8. Hanigan MD, 2004, A model of net amino acid absorption and utilization by the portal-drained viscera of the lactating dairy cow, J Dairy Sci, 87, 4247-68.

9. Kalaitzakis E, Roubies N, Panousis N, Pourliotis K, Kaldrymidou E, Karatzias H, 2006, Evaluation of ornitin carbamoyl transferase and other serum and liver-derived analytes in diagnosis of fatty liver and postsurgical outcome of left-displaced abomasum in dairy cows, J Am Vet Med Assoc, 229, 1463-71.

10. Kida $K, 2002$, The metabolic profile test: its practicability in assessing feeding management and periparturient diseases in high yielding commercial dairy herds, $J$ Vet Med Sci, 64, 557-63.

11. Lamosquet S, Delamaire E, Lapierre H, Blum JW, Peyraud JL, 2009, Effects of glucose, propionic acid, and nonessential amino acids on glucose metabolism and milk yield in Holstein dairy cows, J Dairy Sci, 92, 3244-57.

12. Laven RA, Wathes DC, Lawrence KE, Scaramuzzi RJ, 2007, An analysis of the relationship between plasma urea and ammonia concentration in dairy cattle fed a consistent diet over a 100-day period, J Dairy Res, 74, 412-6.

13. Mohamed T, Oikawa S, Iwasaki Y, Miyunuma Y, Takehana K, Endoh D, Kurosawa T, Sato H, 2004, Metabolic profiles and bile acid extraction rate in the liver of cows with fasting-induced hepatic lipidosis, J Vet Med A Physiol Pathol Clin Med, 51, 113-8.

14. Nafikov RA, Beitz DC, 2007, Carbohydrate and lipid metabolism in farm animals, J Nutr, 137, 702-5.

15. Oeze/ GR, 2004, Monitoring and testing dairy herds for metabolic diseases, Vet Clin North Am Food Anim Pract, 20, 651-74.

16. Ospina PA, Nydam DV, Stokol T, Overton TR, 2010, Evaluation of nonesterified fatty acids and betahydroxybutyrate in transition dairy cattle in the northeastern United States: Critical thresholds for prediction of clinical diseases, J Dairy Sci, 93, 546-54.

17. Payne JM, Dew SM, Manston R, Faulks M, 1970, The use of metabolic profile test in dairy herds, Vet Rec, 87, 150-8.

18. Prodanović R, Kirovski D, Jakić-Dimić D, Vujanac I, Kureljušić B, 2010, Telesna kondicija i pokazatelji energetskog statusa krava u visokom graviditetu i ranoj fazi laktacije, Vet Glasnik, 63, 1-2, 43-52.

19. Rukkwamsuk T, Wensing T, Geelen MJ, 1999, Effect of overfeeding during the dry period on the rate of esterification in adipose tissue of dairy cows during the peripartal period, J Dairy Sci, 82, 1164-9.

20. Schröder B, Breves G, 2006, Mechanisms and regulation of calcium absorption from the gastrointestinal tract in pigs and ruminants: comparative aspects with special emphasis on hypocalcemia in dairy cows, Anim Health Res Rev, 7, 31-41.

21. Stengärde L, Tråvén M, Emanuelson U, Holtenius K, Hultgren J, Niskanen R, 2008, Metabolic profile in five high-producing Swedish dairy herds with a history of abomasal displacement and kethosis, Acta Vet Scand, 50, 31.

22. Šamanc H, Stojić V, Kirovski D, Jovanović M, Cernescu H, Vujanac I, 2010, Thyroid hormones concentrations during the mid-dry period: an early indicator of fatty liver in Holstein - Friesian dairy cows, J Thyroid Res, 2010, ID 897602. 
Acta Veterinaria (Beograd), Vol. 61, No. 5-6, 543-553, 2011.

\title{
PRIMENA METABOLIČKOG PROFILA U PREDVIĐANJU I DIJAGNOZI MASNE JETRE KOD KRAVA HOLŠTAJN RASE
}

\author{
ŠAMANC H, KIROVSKI DANIJELA, STOJIĆ V, STOJANOVIĆ DRAGICA, VUJANAC I, \\ PRODANOVIĆ R i BOJKOVIĆ-KOVAČEVIĆ SLAVICA
}

\section{SADRŽAJ}

Cilj ovog rada je bio da se ispita mogućnost korišćenja rezultata dobijenih određivanjem metaboličkog profila u predviđanju i dijagnostikovanju sindroma masne jetre kod krava holštajn rase. $U$ ogled je bilo uključeno 40 krava holštajn rase u periodu zasušenja, odnosno 5 do 7 dana pre očekivanog termina teljenja. Kravama su uzorci krvi uzeti punkcijom vene jugularis 4 puta i to 5 do 7 dana pre očekivanog termina teljenja, kao i 12., 30. i 60. dana laktacije. U uzorcima krvi određivane su koncentracije ukupnih proteina, albumina, uree, glukoze, BHBA, ukupnog bilirubina, kalcijuma i fosfora. Dvanaest dana nakon teljenja perkutanom biopsijom uzet je uzorak jetre u kome je, patohistološkim pregledom, određen sadržaj ukupnih lipida.

Nakon pregleda tkiva jetre krave su podeljene u dve jednake grupe. Krave kod kojih je stepen zamašćenje jetre bio veći od $20 \%$ (obolele krave, $n=20$ ) $i$ krave bez prisustva masnih kapljica u uzorcima jetre (zdrave krave, $n=20$ ). Mlečnost je praćena svakodnevno od sedmog do 60. dana laktacije.

Dobijeni rezultati su ukazali da je 5 do 7 dana pre očekivanog termina teljenja kao i 12. dana laktacije koncentracija BHBA bila značajno viša $(p<0.001$, pojedinačno) kod obolelih nego kod zdravih krava. Takođe, 12 dana nakon teljenja, koncentracija glukoze $(p<0.01)$ je bila značajno niža, a koncentracija bilirubina značajno viša $(p<0.001)$ kod obolelih nego zdravih krava. Tridesetog dana nakon teljenja koncentracija albumina, glukoze, BHBA i $\mathrm{Ca}$ je bila značajno niža kod obolelih $u$ odnosu na zdrave krave $(p<0,05 ; p<0,01 ; p<0,01$ i $p<0,001$, pojedinačno). Sezdesetog dana nakon teljenja koncentracije ispitivanih parametara se nisu značajno razlikovale između obolelih i zdravih krava. Laktaciona kriva je imala različiti trend kod zdravih i bolesnih krava počevši od 26. dana nakon teljenja. Od tog dana pa do 60. dana laktacije prosečna dnevna mlečnost je bila značajno viša kod zdravih nego obolelih krava, izuzev 32. dana laktacije kada ta razlika nije bila značajna. Na osnovu dobijenih rezultata može se zaključiti da se metabolički profil može sa visokom pouzdanošću koristiti u predviđanju i dijagnostici zamašćenja jetre kod krava Holštajn rase. 